\title{
Text Linguistics and translation: Redefining the concept of "cultural mark"1
}

João Azenha Junior

\begin{abstract}
Since the works of Nida and Taber $(1964,1969)$ on the influence of target cultures on texts to be translated, theoretical considerations on the presence of 'cultural marks' and consequently on analytical procedures that would serve to identify these marks have been more systematically studied as a result of the so-called 'cultural turn' in Translation Studies (Reiss 1971, 1983; Nord 1988, 1993; Snell-Hornby 1986) and heavily criticized by the Deconstruction approach to translation (for instance, Arrojo 1986, 1992). The development of Text Linguistics has also contributed to enlarge the boundaries of the concept, bringing it, so to speak, from the outside world - where it seemed to be embedded in the $60 \mathrm{~s}$ - to the inner domain of the text itself and discourse. This paper aims at briefly revising this conceptual turn and at discussing its consequences for translation teaching. Examples taken from German texts translated by Brazilian students shall demonstrate how efficient the systematic use of text linguistics concepts can be to help students in identifying layers of meaning which, distant from the idea of 'cultural marks' as a reference to a concrete reality, define a point of view in the source text, legitimate interpretations that demand shifts in the target text and therefore can also be taken as cultural in a broader sense.
\end{abstract}

Keywords: Text Linguistics; cultural marks; translation teaching.

\footnotetext{
${ }^{1}$ Tradução para o inglês de Alvamar Helena de Campos Andrade Lamparelli.

University of São Paulo. The author thanks Prof. Dr. Masa Nomura for revising the concepts of Text Linguistics employed in this study.
} 
The notion of referent, of connection of a lexical item to reality which is external to the text, is a legacy embedded in common sense and, therefore, brought in the baggage, so to say, by translation students. Such notion, grounded on the opposition "linguistic world vs real world", underpins a notion of text as mirror of an extralinguistic reference and result of an action not mediated by a subject.

Since the works of Nida and Taber (in the 1960s) ${ }^{2}$ and Translation Studies of structuralist foundation ${ }^{3}$, two concepts find echo until now among Brazilian translation students: on the one hand, a split between the linguistic and the extralinguistic world; on the other, the notion of a culture residing outside the text, that is, pertaining exclusively to world external to language. As a result of that, the notion of a "cultural mark" present in the text would be associated to issues concerning specific features of the cultural universes at stake and would become a translation problem the moment when, being peculiar to the culture in which the source-text was generated, it failed to be identified and understood by the culture to which the translated text is addressed.

As a matter of fact, the notion of culture as a universe alone, disconnected from the linguistic universe, has kindled the discussion on translatability and untranslatability from the beginning of the nineteenth century ${ }^{4}$ up to the 1970s, approximately. WILSS (1982), for example, comments:

Cultural untranslatability occurs when sociocultural factors cover a different range of experience in the SL [source language] and the TL [target language] and must be made to coincide in regard to the intended meaning in each instance. (WILSS, 1982: 50)

Wilss'statement, besides encouraging the idea of a split between language and reality, considers experience a phenomenon which can be objectively measured and defends the notion of an existing "intended meaning" by the author and by the translator,

\footnotetext{
${ }^{2}$ Cf. NIDA (1964) and NIDA and TABER (1969).

${ }^{3}$ Cf., among others, MOUNIN (1963) and CATFORD (1980).

${ }^{4}$ Here I refer particularly to the reflections of Wilhelm von Humboldt and Friedrich Schleiermacher, just to mention two German language philosophers of the time, who addressed issues concerning translation.
} 
which is - by the same token - susceptible of being objectively grasped. Such standpoint adopted by Wilss, which addresses translation issues from a perspective external to the object being addressed, began to be more systematically opposed around the end of the 1970s.

By this time, the criticism of Translation Studies influenced by the deconstruction approach towards the structuralist model, centered on logos, challenged the severance subject-object in relations operated through language and inside language, and- as a result of that- vindicated the definitive insertion of a mediating subject and of his point of view in the constitution of the meaning in language. And the works of Nida and Taber, as well as of authors grounded on structutralist foundation are called into question by studies which criticize the notion of a meaning which can be conveyed from text to text, from culture to culture, even if in different (linguistic) forms. ${ }^{5}$

Also in the middle of the 1970s, the so-called "cutural turn" in Translation Studies breaks ground for the interdisciplinary dialogue ${ }^{6}$, broadens the concept of culture so as to encompass all the manifestations of the human spirit; views the relation between the linguistic and the extralinguistic world as a continuum, redirects the function of translation to the receiver and - being the subject-translator in the center of the decision makinghighlights the resort to stereotypes when defining the functional strategies of translation. ${ }^{7}$

Alongside this evolution, the insertion of the subject and his entwined relation with an object- whether the world of experience, or the text and the discourse- also feature in recent studies of Text Linguistics:

(...) we perceive the object as previoulsy defined by our cultural practices:
"reality" is built from a whole net of cultural stereotypes which condition
perception itself and which, in their turn, are granted and reinforced by
language, in such a way that the process of knowledge is regulated by a
continual interaction of praxis, perception and language,. (KOCH, 2004:
51, author's emphasis).

${ }^{5}$ Cf., for example, ARROJO (1986, 1992).

${ }^{6}$ Cf. among others, SNELL-HORNBY (1986) and her reflection on a "holistic view" of the translation process, articulated with the most varied fields of knowledge.

${ }^{7}$ Cf. REISS (1971, 1983), NORD (1988, 1993). 
What is meant by that is not that the referent - the extralinguistic "thing" as defined by $\mathrm{KOCH}$ (2004) - no longer exists as such and also as a translation problem, associated, for example, to the notion of Realia ${ }^{8}$. Specific features of cultures have always stood and will always stand as problems of understanding, whether in the domain of the text and discourse, or outside it. And that is so despite the breakthoughs available by electronic survey, which were not - nor could have been - envisaged in the reflections of Nida and Taber of the 1960s. However, such as it is conceived today, referent owes its existence to a "(non verbal) process of cognition, of construction and of ordering of the universe" (KOCH, 2004: 52; my emphasis), operated inside the discourse.

As a result of that, the construction of meaning in translation- even for those instances in which significant differences are found in the way two cultures view the same event- shifts from the notion of referent to the activity of referentiation, this latter being understood not as a relation between what is "inside"and what is "outside" the text, but rather as a range of resources the text producer, on one side, and the reader on the other, avail themselves in order to construct, deconstruct and reconstruct chains of meaning. This intertwining of threads conductors of sense is only knitted into shape in the interaction and seems to have currently come to the fore in Text Linguistics. KOCH (2004) summarizes:

Well: if the referent is built by social practice, what about the sociocognitive and discoursive activity of referentiation? This is one of the main reflections Text Linguistics is engaged in today. (KOCH, 2004, 53).

In this study, my considerations on the contribution of Text Linguistics for working in translation classes are restricted to the lexical field. ${ }^{9}$ By means of examples taken from work carried out with translators at beginner level in the University of São Paulo, I seek to demonstrate that lexical items, provided they are considered in their interrelationship inside discourse, establish semantic fields which help students identify points of view in the

\footnotetext{
${ }^{8}$ On the notion of Realia and of its consequences for translation, cf. MARKSTEIN, 1999.

${ }^{9}$ For a more comprehensive view on the contributions of Text Linguistics for translation, whose discussion would outstrip the boundaries of this work, cf., for example, KAPP (1974), BELL (1991) and FAWCETT (1997).
} 
source-text, legitimize interpretations which ask for adjustments in the target texts, and as a result of that, can also be seen as cultural marks in a broader sense of the term.

\section{Inside the text and the discourse}

Since Halliday's and Hasan's work, Cohesion in English, (1976), the relations of sense woven inside the texts have been more frequently investigated in a form more integrated with other approaches of language studies- for instance, the functional and cognitive perspectives- within which, and following a similar path, Translation Studies also lie.

Until the middle of the 1980 s, an attempt is felt which seeks to separately define two of the seven textuality criteria described by De Beaugrande and Dressler in 1981 cohesion and coherence- as phenomena associated, in the first case, to the linear chaining of the components of the text surface, and, in the second, to dependencies of conceptual nature. Taking a retrospective look, such a conception seems to bolster the idea that the senses are capable of organizing themselves and surviving within the text, irrespective of the action of the subject-reader (and also of the translator), provided that the rules of the linguistic systems at stake are respected. It is as if the lexical choice and the arrangement of the elements in the text surface, so long as they are connected according to rules provided by grammar, were able to ensure the stability and the efficacy of a sense supposedly intended by the author of the text and unaffected by the actions of time and of its readers.

Although still largely accepted and shared by students beginning to learn a second language and also translation, such a concept no longer withstands a stricter investigation. BAKER (1992), for instance, when referring to the definitions of cohesion and coherence, comments:

In the case of cohesion, stretches of language are connected to each other by virtue of lexical and grammatical dependencies. In the case of coherence, they are connected by virtue of conceptual or meaning dependencies as perceived by language users (BAKER, 1992: 218; my emphasis). 
Further to that, FAWCET (1997) states:

\begin{abstract}
"Coherence" is the twin of "cohesion", but it is a rather more difficult concept to define. It involves not only such matters as the conceptual logic of how a text is structured, which will often be reflected in cohesive devices, but also knowledge of such things as subject matter and how the world works (FAWCETT, 1997: 98; author's emphasis)
\end{abstract}

Coherence, thus, is no longer something inherent to the text itself, and it can only be achieved in the interaction with the language user, the reader or the translator. In this process the text shifts from mere repository of previously defined senses, to starting point for a network of associations and dependencies effected in the act of reading and which defines its singularity. Once the distance between an object (the text itself) and a subject (its reader and translator) is abolished, the relations of sense are built upon each interaction and differently. This notion of interaction grounded on experience accounts for the interpretation shiftings of the "same" linguistic phenomenon and underlies the reflection herein proposed aiming at a broadening of the concept of "cultural mark".

Much as all this may sound rather obvious to the language scholars, this is not the case for translation students. And even getting acquainted with such reflections, on the theory level, does not mean that the concept will be assimilated by them and put into practice, whether in the preliminary phase for translation, or later, in the critical appraisal of the work. Comments such as "- but the dictionary says so", or, "- but I found such equivalent in the Internet", or even "- I think what the author meant in this passage was....", among many others, confirm the split between subject-object and underpin a fragmented view of language, in which the word alone, without relation to its environment, still lies at the forefront. Except for some cases, the translator student insists on working the text linearly, convinced that he will attain the meaning supposedly intended by the author provided that he clings, in the surface, to the distribution of elements in the sentence, and, in the field of syntax, so long as he respects the rules of the system to which he is translating.

Provided with some guidance, however, beginner translators are likely to perceive that the interrelation of the lexical items organizes and reorganizes chains of meaning at 
each phase of reading and may establish semantic fields capable of activating frames, scripts and cognitive schemas, which at times ensure the continuity of the theme addressed, at others trigger ruptures which indicate thematic unfolding. In this context, the "cultural mark" of the text to be translated - understood rather as the way in which each one reads and interprets the world- shifts from the relation between a lexical item and its counterpart in the extralinguistic universe into the intertwining of the discourse.This shifting gives rise to critical issues for the translator, as reminded by BELL:

\begin{abstract}
“(...) the attempt to get the text to 'make sense' (...) raises a number of questions which are of considerable significance for the translator: (a) which world are we attempting to match with the text, given the subjectivity of personal experience, the certainty that different cultures perceive (or, at least, model) the world differently?, (b) how can we act upon the realization of the highly interactive nature of text? and (c) how can we come to any principled understanding of text-processing, unless we find ways of relating 'real world' and 'text world' together in a way which 'makes sense' for us?” (BELL, 1991: 166-167; author's emphasis).
\end{abstract}

\title{
What (on earth) is Stalin doing in the funeral of John Paul II ?
}

St. Peter's Square, Rome, April 9, 2005. An unprecedented media coverage allows the world to watch the funeral of John Paul II. The text of the online edition of Der Spiegel magazine (cf. Annex), by Rome-based correspondent Dominik Baur ${ }^{10}$, describes and comments the cerimony. In São Paulo, a group of students reads and discusses, in almost real time, Baur's text. They peruse the text to be translated. The conditions for comprehension are favourable, after all, despite being students beginning to learn German as a second language, there is ample shared knowledge of the world: they have all followed the agony and death of the most popular Pontiff of the Catholic Church.

The classroom work starts by ascertaining the place where the reporter speaks from. Baur's text purports to be, as the reporter is himself, anchored in Rome. This anchorage is

\footnotetext{
${ }^{10}$ The text used for the selection of examples is entitled "Ruhe nach der Invasion der Pilger" (Peace after the pilgrims'invasion) and was published in the online version of Der Spiegel magazine on the $10^{\text {th }}$ of April, 2005. The text was analysed in the classroom by students beginning to learn German as a second language in the University of São Paulo, Brazil.
} 
actualized by a wealth of lexical items which reconstruct in the text, the Italian capital and which are connected whether by co-reference - that is, by the use of textual deictics, proforms, etc -, or by substitution and ellipsis. That is to say, by mechanisms of recurrence and reference. ${ }^{11}$

(1) Aus Rom berichtet ...

[from Rome reports...]

(2) Eine Stadt atmet auf ...

[A city breathes relieved...]

(3) Millionen Menschen (drangen) ... in die italienische Hauptstadt.

[Millions of people flooded to the Italian capital...]

(4) Selbst im Vatikan herrscht touristischer Alltag ...

[Even in the Vatican the movement of tourists returned to normality...]

(19-20) ... Pilger, die ... in die Ewige Stadt gekommen waren, ...

[Pilgrims, who had arrived in the Eternal City...]

(21) Am Ufer des Tibers, gegenüber von der Engelsburg ...

[On the banks of the Tiber River, in front of Sant'Angel Castle...]

(25-26) Am Petersplatz hat sich die Lage ... normalisiert ...

[In St.Peter's Square,... things returned to normality...]

(28-29) Am Obelisken in der Mitte des [Peters] Platzes ...

[Close to the Obelisk, in the middle of the Square (St. Peter's)...]

(35-36) ... die zum Petersplatz führende Via Conziliazione ...

[Via Conziliazione, which leads to St.Peter's Square...]

(40) ... die Schlange derer, die in den Dom wollen, ...

[the queues of those who want to enter the Basílica...]

(44-45) Erst am Montag öffnet der Vatikan seine Krypta wieder ...

[Vatican will reopen its Crypta only on Monday ...]

(49) Im Kirchenstaat haben ... die Novendiale begonnen ... [The Novendiale began in the State of the Church ...]

(50) Täglich wird im Petersdom eine Messe ... zelebriert... [A mass a day is celebrated in St.Peter's Cathedral]

(53) ...die Kirchenführer [begeben sich] dann in die Sixtinischen Kapelle ...

[The leaders of the Church then head to the Sistine Chapel]

The use of these recourses which situate the event in space and time and which aim at determining the place (concrete) from which Baur speaks, is reinforced by direct or indirect allusions to voicings of institutions, authorities and ordinary citizens:

(37-39) 1,4 Millionen Menschen, heißt es heute im italienischen Innenministerium, seien in diesen Tagen an dem aufgebahrten Leichnam vorbeidefiliert ...

[1,4 million people, according to today's announcements of the Italian Ministry of Interior, are believed to have marched these days past the Pope's coffin...]

(55-56) „Grazie!” ... steht heute ... auf der Titelseite des ,Osservatore Romano“ ...

[,Grazie!“ ... the headline of Osservatore Romano reads today...]

\footnotetext{
${ }^{11}$ In the examples shown in this study, the number in parenthesis refers to the line in the text in German from which the excerpt is drawn. (cf. Annex).
} 
(58-61) Es sei als müsse man ein Jubiläumsjahr ... organisieren, hatte ... Bürgermeister Walter Veltroni geklagt, aber das in nur zwei Tagen.

[It is as if we had to organize a jubilee... - complained Mayor Walter Veltroni -, except that in only two days].

(68-69) Staatspräsident Carlo Azeglio Ciampi dankte den Römern, ...

[President Carlo Azeglio Ciampi thanked the Romans...]

(70-71) Auch US-Präsident George Bush, der britische Premier Tony Blair und Spaniens König Juan Carlos stimmten in das Lob ein.

[Even the President of the United States, George Bush, the British Prime Minister, Tony Blair and King Juan Carlos of Spain joined the chorus of praise...]

(73-76) Ein Kellner einer Pizzeria ... beschwert sich: „Wir sind leer ausgegangen.“ Er habe gedacht, wenn die Pilger kommen, werde er einen viel größeren Umsatz machen. „Aber die haben ja alle nur Sandwichs gegessen.

[A waiter from a pizzeria... grumbles: "We had no profits". He had believed that when the pilgrims arrived, the profit of the business would be much greater. "But all they ate were sandwiches".]

Benefitting from the digital environment in which the text is conveyed, the anchorage is further reinforced by the possibility offered to the user of setting out in a "virtual trip by the Vatican", through a mere click on the correspondent icon (Fig. 4). Furthermore, the enhanced information technology still offers the section "Zum Thema" (About this topic), in which the reader is allowed access, through links, to other articles of the magazine concerning the same subject.

Despite the use of all these resources, the course of the analysis challenges the fact of Rome being the place from where Baur speaks. And the Eternal City starts to be abandoned the moment when Stalin, through Baur's voice, shows up in St. Peter's Square and asks: - How many divisions has the Pope got? (17). To Brazilian translation students this allusion to the Soviet leader sounds rather peculiar: - What (on earth) is Stalin doing in the funeral of John Paul II?, they ask. It is at this moment, by starting to reconstruct relations, that one will be lead to reconsider the place where the text to be translated is anchored, and its difficulty level.

As a matter of fact, Stalin's question and its echoes in Brazilin students prompt a rereading of the text, this time with the attention turned to a portion of the lexicon which suggests a layer of meaning superposed to the first. Covering an allegedly informative character, this "coat" suggests an unfolding, in the political sphere, of the facts described. Would the allusion to Stalin be associated with the fact of the Pope having cooperated to the dismantling of the socialist block? And at this point, as we are still within the 
boundaries of the stored previous knowledge, the text is reread with the attention turned to evidence which might be related, in the memory of the student-readers, to such knowledge. Indeed, from the very title itself onwards, we read:

(0) Ruhe nach der Invasion der Pilger

[Peace after pilgrims'invasion]

(14) Doch der Begeisterung der Massen Abbruch zu tun ...

[But to thwart the excitement of the ...]

(36-37) ... Pilger aus aller Welt Schlange standen, um dem Pontifex die letzte Ehre zu erweisen.

[Pilgrims of the whole world queued up to pay their last homage to the Pontiff.]

(37-38) 1,4 Millionen Menschen, ..., seien an dem ... Leichnam vorbeidefiliert ${ }^{12}$

[1,4 million people... are believed to have marched past the coffin...]

(41-42) Um trotz der Sicherheitskontrolle, ...

[And despite the security control,...]

(54) Solange sie (die Kardinäle) tagen, bleiben die Zugänge vermauert ${ }^{13}$

[While they (the Cardinals) remain convened, entrance (to Sistine Chapel) is interdicted]

(66-67) Beim Abzug ${ }^{14}$ der Menschenmassen aus der Stadt, ...

[While people make a retreat, leaving the town,...]

(73) Denn die wenigsten haben von dem Ansturm ${ }^{15}$ der Millionen profitiert.

[For just a few people had profits with the investing of millions (of people).]

(76-77) Restaurants konnten sich die zumeist jugendlichen Papstanhänger ${ }^{16}$ offenbar nicht leisten.

[It appears that the followers of the Pope, the majority of them young, could not afford the privilege of eating in restaurants.]

A close look into the relations between the lexical items mentioned not only hones the students' senses to a portion of the lexicon they were unaware of and connects this portion to historical facts, but also confirms the suspicion about the existence of an interpretation layer of political and ideological nature. Its existence enables one to also reconsider the allusion to Bush, Blair and Juan Carlos, three among the more than two hundred Chiefs of State attending the cerimony. Whether a coincidence or not, the three political characters were America's partners in the war against Iraque, which was strongly criticized in the German sphere.

12 DUDEN Universal Wörterbuch (1996: 324) registers for this verb the sense of a solemn march, like the military parade, and the review of troops before authorities.

${ }^{13}$ The verb "vermauern" (cf. DUDEN 1996: 1654), used here in the sense of interdiction (to the entrance to the Sixtine Chapel), has the noun "Mauer" [wall] in its root. Although we cannot assert this was an intended use, its relation in this semantic field with the wall which divided the two blocks is not only feasible for the Brazilian student but also justified.

${ }^{14}$ For this term we find- in the military sense of the entry (cf. DUDEN 1996: 76) - the retreat, for example, of the troops.

${ }^{15}$ Derived from the verb anstürmen, the noun Ansturm appears, for example, associated with the attack of the enemy, which legitimizes its inclusion in the lexical field of war (cf. DUDEN 1996: 125).

${ }^{16}$ The noun Anhänger, in the uses described in the dictionary (cf. DUDEN 1996: 112), is employed to describe the follower of a philosophic or ideological line or the militant worker of a party. 
In the light of this path of interpretation, three references to Poland and to the Polish also stand out, since not only is Poland birthplace of the deceased Pope but also a country pertaining to the ex-communist block. Let us take, first, the following scene in St. Peter's Square: after the cerimony, a municipal employee shovels a pile of garbage left by the cerimony participants (or rather, by the pilgrims, as Baur prefers): there are candles, flowers and bottles of water. In the end of the paragraph, we read:

(32-34) Eine polnische Touristin fischt sich noch schnell ein paar unbeschädigte rote Plastikrosen aus dem Haufen. [Rapidly, a Polish tourist still manages to fish from the garbage some red plastic flowers, not spoiled yet].

Inside the texture of the discourse which is being woven by the previous considerations, the Brazilian students deem it relevant to ask: - But why precisely a Polish tourist? And why red flowers, tokens of socialism? And why are they plastic flowers, that is, fake flowers? And, finally, why are they in the garbage? Wouldn't this be too strong a condensed image? Another difficult question for the Brazilian students to grasp: wouldn't that be a dispensable detail? What does it add to the description of the facts? And finally, isn't it derogatory for the Polish to be mentioned in a journalistic text, catching things from the garbage? In addition to this, the Polish issue is further reinforced by two other passages:

(21-23) Am Ufer des Tibers, gegenüber von der Engelsburg, steht noch ein letzter der polnischen Reisebusse, die die Pilger aus der Heimat des Papstes zum Vatikan gebracht hatten.

[On the banks of the Tiber River, in front of Sant'Angel Castle, the last of the tourist coaches which brought the pilgrims from the Pope's hometown to the Vatican is still parked].

(76-78) Restaurants konnten sich die zumeist jugendlichen Papstanhänger offenbar nicht leisten - kein Wunder, denn selbst der monatliche Facharbeiterlohn eines Polen schmilzt in einem römischen Restaurant wie Eis in der Sonne.

[It appears that the followers of the Pope, the majority of them young, could not afford the privilege of eating in restaurants. No wonder, for even the monthly wage of a skilled Polish worker would melt in a Roman restaurant like ice-cream under the sun.]

The first passage, in itself, would depict no derogatory bias in relation to the Polish. However, on the track of the previous questions, the translation students ask: - But were the coaches parked on the banks of the Tiber River only Polish tourist coaches? The second, in the end of the text, on the other hand, is rather incisive in relation to the purchasing power of the Polish and prompts us to review the interpretation of the previous passage: - The 
Polish then, probably cannot afford to travel by train or by plane to Rome, they comment. To the eyes of Brazilian students, the three passages let out a critical view- and we could even say, an ironical one- with regard to the ex-communist block, besides conveying not so endearing a viewpoint in relation to the Polish. And whose view might this be? The reporter's? The magazine's editorial line? The Germans's? Irrespective of this being confirmed or not in practice, a perusal of the text taking into account the relations of lexical cohesion, enables one to raise such questions. And they hint at an opinion anchored in a different cultural reality from the Brazilian one.

The question of irony, mentioned above, allows us to venture interpretations for the view of the reporter on the events he is describing, this time, with regard to the cerimony itself. The callout text already brings in the term "Papaboys" and the reference to the participants along with the illustrations which uphold the article in the following text, allows the ensemble to be associated with a pop star show:

(2) Die Präsidenten und Papaboys haben Rom verlassen.

[The presidents and the papaboys left Rome.]

(16) Die Millionen Fans ... jubelten ihrem toten Idol zu... [Millions of fans jubilantly greeted their deceased idol ...]

(Fig. 2) Die Folgen des Mega-Events wurden schnell beseitigt (legend of the photograph).

[What was left of the mega event was rapidly cleared away ]

(46-47) ... keine Papaboys oder-girls, wie sich die jugendlichen Fans des Papstes nennen [No papaboy or papagirl, as the young fans of the Pope are called,...]

(48) ... die (Fans), die ... den Vatikan zu einem Festival des Glaubens besucht hatten. [(fans), who had visited the Vatican for a festival of faith.]

An examination of this portion of lexicon unveils a certain disregard as to the seriousness of the event, the solemnity of the funeral and the truly poignant sense of the cerimony. Such interpretation, more easily identified by Brazilian students, is reinforced by the opening paragraph of the text. In it, Baur comments the action of the wind on the robes of the cardinals- a caricatured image bolstered by the illustration accompanying the text (Fig. 3) - and on the "Book of the Books":

(10-13) Mit den Soutanen der Kardinäle trieb er [der Wind] Schabernack, das Buch der Bücher auf dem Sarg klappte er, nachdem er eine Weile durch die Seiten geblättert hatte, ganz zu. [It (the wind) played around with the robe of cardinals and slammed the Book of the Books shut, after having flipped through its pages for some instants] 
Strictly speaking, and according to the explanations broadcasted on TV by experts in Vatican ceremonials, the wind (a metaphor for God's hand?) should select an excerpt from the Evangel to rule and inspire the cerimony of the funeral. If the wind makes the presence of the cardinals a laughingstock, and without picking a passage from the Evangel, shuts the book down, the genuinely religious spirit of the cerimony is impaired and what we see- and read- afterwards is the description of the "morning after"of a pop star show.

\section{If we are to translate, then what should we translate?}

Based on shared previous knowledge, in this case, the death of Pope John Paul II, the text at study withstands a linear analysis and treatment and only succeeds in unveiling layers of meaning superposed to its alledged objectivity, provided that it is read and discussed after an examination of the lexicon based on the interrelation, and that established semantic fields grounded on such examination are taken into account. This way, what could be called cultural mark here, may and ought to be assessed in relations which activate cognitive schemas and make it possible to identify different angles, from which the reporter observes what he is describing and commenting.

The discussion of such aspects enables one to inquire about the very nature of the journalistic texts, to address the notion of objectivity and of commitment to the truth commonly assigned to this kind of text, to perceive some features of the opinion-ridden journalism and reflect on some editorial lines. In the domain of translation, this exercise allows one, still, to inquire whether translation procedures for this kind of text should not only take into account issues concerning the linguistic systems at stake, but also- and foremost- the cultures and the very system of the press in effect in the country to which the translation is designed ${ }^{17}$.

Furthermore, that which for the reader in the German linguistic environment would have a more easily identified meaning- for instance, the reference to history, to the division

\footnotetext{
${ }^{17}$ Cf. ZIPSER (2002).
} 
of Europe in blocks of different political and ideological orientation, the conjuring up of an image of Polish people which was built (or which is held) and the association of the event described with a pop festival (which can also be seen as a criticism to the Catholic Church itself, in a continent where its followers have been fleeing), all this seems rather remote with respect to the horizon of expectations of average Brazilian readers. These are dimensions of meaning whose access they are not likely to obtain on their own and which, therefore, rather than informing, will have the effect of hindering comprehension.

Finally, the very purpose of the article, that which could be considered the fact which prompted its writing- "Peace after pilgrims'invasion" - might be challenged at the moment of translation. After all, the whole article concentrates on finding out, much to its surprise, that despite all the flood of the faithful, despite all the traffic clutter in the city of Rome, despite the heat etc., everything turned out fine. Well, the only reason which would account for this turning into an article in the press would be the existence a priori of an expectation to the contrary. That is, if what was expected were problems of organization which resulted in chaos. For Brazilians, there is no such expectation a priori that the Italians are not exactly what the Germans might call an example of organization. In this sense, then, the article would also have no reason to exist. - Did the Germans believe the Italians would not be able to cope with an event of such a dimension? The students ask, wondering whether the proposed text would really have something to say to the Brazilians.

Thus, by dismissing the first impression that an informative text conveyed online would not contain "cultural marks", the preliminary work for translation encourages a redefinition of this concept, to be sought no longer in the so-called "extralinguistic reality", but rather in the way each culture sees the world and reconstructs it inside the discourse.

\section{References}

ARROJO, Rosemary (1986) - Oficina de tradução. A teoria na prática. São Paulo, Ática.

ARROJO, Rosemary (1992) - O signo desconstruido. Implicações para a tradução, a leitura e o ensino. Campinas (SP), Pontes.

BAKER, Mona - (1992) In other words. A coursebool on translation. London \& New York, Routledge. 
BELL, Roger (1991) - Translation and translating. Theory and Practice. London and New York, Longman. CATFORD, J.C. (1980) - Uma teoria lingüistica da tradução. Campinas (SP), Cultrix/PUC.

De BEAUGRANDE, R.A.; DRESSLER, W.U. (1981) - Einführung in die Textlinguistik. Tübingen.

FAWCETT, Peter (1997) - Translation and Language. Linguistic theories explained. Manchester, St. Jerome Publishing.

HALLIDAY, M.A.K. \& HASAN, R. (1993) - Cohesion in English. London, Longmann (1a. ed. 1976).

HATIM, Basin and MASON, Ian (1997) - The translator as communicator. London and New York, Routledge.

KAPP, Volker. (1974) - Übersetzer und Dolmetscher. Heidelberg, Quelle \& Meyer (UTB 325)

KOCH, Ingedore G. Villaça (2003) - Desvendando os segredos do texto (2 ${ }^{\mathrm{a}}$. edição). São Paulo, Cortez.

KOCH, Ingedore G. Villaça (2004) - Introdução à Lingüística Textual. São Paulo, Martins Fontes.

MAINGUENEAU, Dominique (1996) - Elementos de lingüistica para o texto literário. São Paulo, Martins Fontes.

MARSTEIN, Elisabeth (1998) - Realia. In: SNELL-HORNBY, Mary et alii (ed.) - Handbuch Translation. Tübingen, Stauffenburg.

MOUNIN, Georges (1975) - Problemas teóricos da tradução (Trad. Dominique Aury). São Paulo, Cultrix.

NIDA, Eugene (1964) - Toward a Science of Translating. Leiden: Brill.

NIDA, Eugene e TABER, Charles R. (1969) - The Theory and Practice of Translation. Leiden: Brill.

NORD, Christiane (1988) - Textanalyse und Übersetzen: theoretische Grundlagen, Methoden und didaktische Anwendung einer übersetzungsrelevanten Textanalyse. Tübingen, Narr.

NORD, Christiane (1993) - Einführung in das funktionale Übersetzen. Tübingen: Francke (UTB).

NORD, Christiane (2003). Kommunikativ handeln auf Spanisch und Deutsch. Ein übersetzungsorientierter funktionaler Sprach- und Stilvergleich. Wilhelmsfeld: Gottfried Egert.

REISS, Katharina (1971) - Möglichkeiten und Grenzen der Übersetzungskritik. München, Hueber.

REISS, Katharina (1983) - Texttyp und Übersetzungsmethode. Der operative Text (2 ${ }^{\mathrm{a}}$. ed.). Heidelberg, Groos.

SNELL-HORNBY, Mary (ed.) (1986) - Übersetzungswissenschaft. Eine Neuorientierung. Tübingen, Francke Verlag (UTB für Wissenschaft: Uni-Taschenbücher; 1415).

WILSS, Wolfram (1982) - The science of translation. Problems and Methods. Tübingen, Narr.

ZIPSER, Meta (2002) - Do fato à reportagem: as diferenças de enfoque e a tradução como representação cultural. Tese de Doutorado. São Paulo, FFLCH-USP. 
SPIECEL ONLINE = 00. April 2005, 16:21

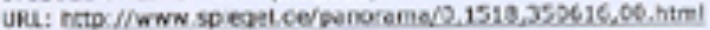

Rom

\section{Ruhe nach der Invasion der Pilger}

Ane Pors bavichter Demink Bxur

Tine Stadt atmet auf: Die Präsidenten und Papabora haben Asm verlassea. Nachdem Mistonen Merechnn in dan vargangenen Tagen in de itallenische Hauptstadt crangea, kehrt jetet wieder Ruhe ein. Selbat im Vatikan herrscht teuristischer Alltag an Tag danach.

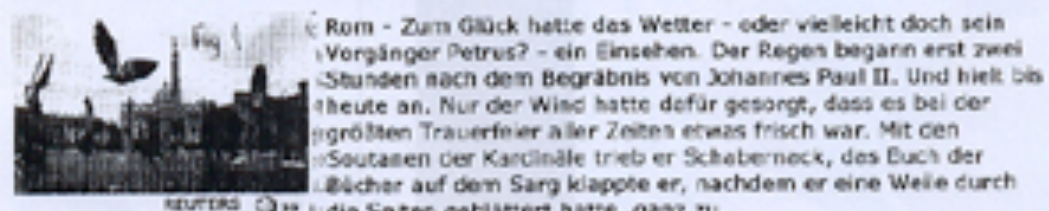
Niturelab noch des

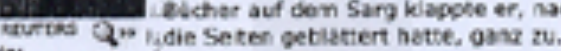

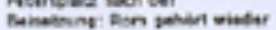

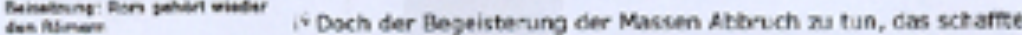
isauch ciss kuhle Laftuter richt. Oie Maliven rans won Jehannes

, Naul II. jubeltes ihren toten ISsl zu und beantwortbten gestert auf teeindrucken de Weike "rde Gberhebliche Frace, de einst Stalin stelise: "Wie veie Drvisionen hat cer Papst?" Docs der ¿Sowjeufuher hatte oxh nicht Karcll Woltya vor Augen, als er vorn Fopst sproch.

i Nun gebsrt Rom wieder den Romern. Der alkergrobte Tell der bs au vier Hilloven Piger, de cru dem Begsbbnis is de Exige Stadt gekommen waren, hat sich beceits gestem Nachmittac i wieder aef die Heimreise pengche. An ufer ces nibers, gegenuber von der Engeliburg, steht wnoch eis letrter der poinischen Reibebusse, de Sie Plger aus der Heimat des Fapstes zum vatikan gebracht batien.

Ansonsten hat sick de Menge der Fremden in der Stadt wiader in der oblches Grobenordsuag einoticenselt. Am Petersoatz sat sich die Laoe uber Nechl eten/elis normelis ert. Der Mal, cen Hunderttousendo thinterasten taben, ist am Vormittay schen faut galnales bestitiot worden. Arbeiter baven de ketaten Absperrunsen und Tribanen ab. Am Obelisken in der Mitte des Potzes ist gersde de Millabluhr an Werk. En Mann schautet Kerzen, Bumen und Wasserflascheh in uein kle nes Mallauto. Auch rahleiche Fahnes, die die Piger aus den verschiodensten LEndern - ncht mehr m thehmen wolted, steheh hier. Fise poln sche Tauristin fische isich noch schnel ein par unbexchasigte fose Plast krosen aus dem Haufon.

Auch der Verkehr rolit wieder dunch die zum Peterspiatz fuhrende Via Conciliazions, in der fast eine Woche die Alger aus aller Wek Schlange

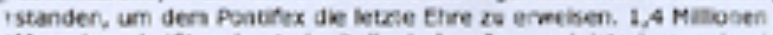
Menschea, heilet es heuto in ikalienischen Insenministerium, seian in jesen Tagen an dem aufgebahten Leichnam verbeidefiert.
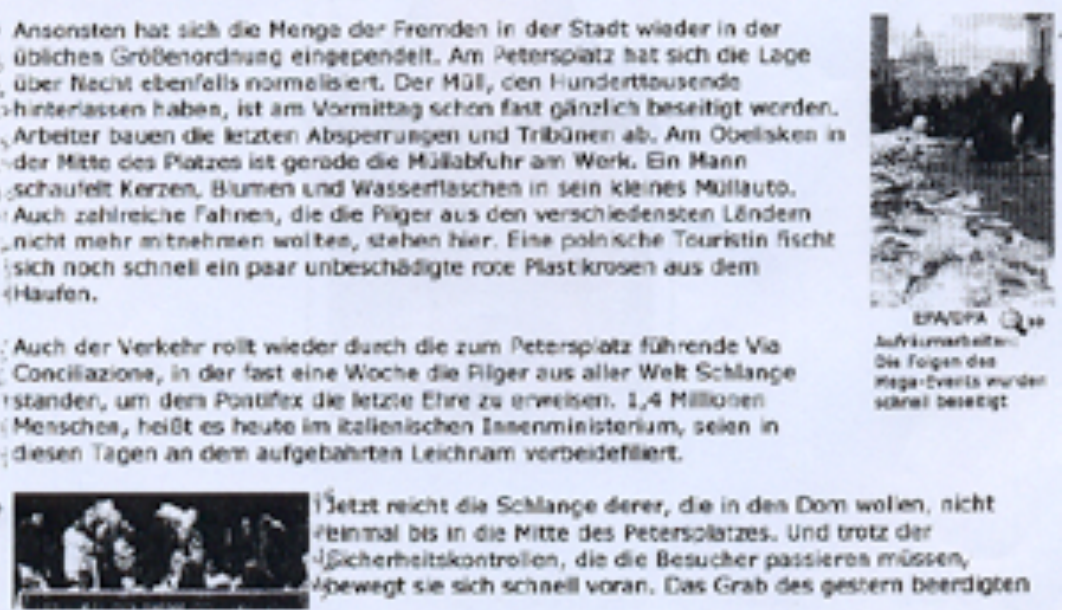

i Getat reicht dia Selange derer, de in des Dom wolen, nicht rein mal bis in oia Nitte des Petersolatzes. Und trotr der ificherheittkontrolen, die de Besucher passieres missen. Shewegt sie sich schnell voran, Cas Grab des pestern betrigken 
Druckvernion - Rom: Ruhe nach der Invasion der Pilger - Panorama - SPIEGEL ON Pigina 2 de 3

wuress Q ma Papstes kónnen sie jedoch heute nicht sehen. Erst am Montag

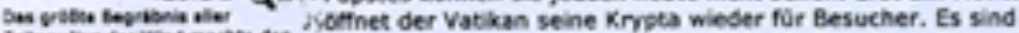

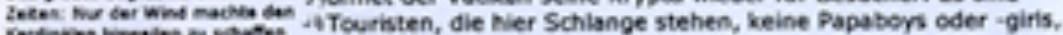

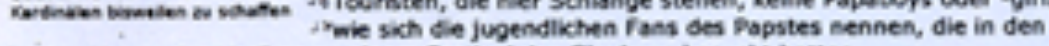
i letzten Tagen den Vatikan ru einem festival des Glaubens besucht hatten.

I Im Kirchenstagt haben dermell die Novendiale begonnen, die neuntagigen Traverfeiern. "Tsolich wird im Fetersdom eine Messe for den toten Pasut xelebriert, wahrend hinter i verschlossenen Turta bereits der Countoown zum Konklave begonien hat. Die Kardinale serbreches sich nun den Koof Ober einen Nachfolger won Johannes Paul II. Ab dem 18. Agril - begeben sich die Kirchenfuhrer dann in die Sixtinischen Kapelle, um den Nachlolger Karol Wojtylas zu bestimmen. Solange sie tageh, bleiben die Zoginge vermavert.

"Grazier" Ganz einfach hor "Danke" steht heute in proden I Lettern aut der Trelseite des "Osservatore Remano", der "Tagesaeitung des Vatikans. Und in der Tat: Stadt und Staat i haben Grund aum Stok, ts sei als musse man ein

1 Jubllumsjahr wie vor fund lahren das Helloe Jahr

corganiaieren, hatte Anfang der Woche Bürgermeister Waiter Veltroal geklagt, aber das in nur zwei Tagen. Doch dans ging alkes reibungubs. Die firvasion der Prasidenten und Popaboys ging ohre grbiere Zwikchenfalk vorober.

-Niemand kam im Cedrange ernsthan ru Schaden, und auch nat:-6asix die Skcherheit der nund 200 stagts- und Regierunguchets mar i Gealhrlestet. Beim Abzug der Menschenmassen aus der Stad hatte es nicht einmal mehr \&as beforchtete Verkehrschaos gegeben. Es scheint, als ifuhrten nicht alle Wege nach Rom, sondem noch mehr aus der Stadt heraus. Stastsprasident Carto Aatglio Ciampl dankte den Romern, die Cie Ploer trotr aller Behinderungen agastfreunolich emplangen hatten. Auch US-Prasident George Bush, der britische Premier ITony Btair und Spaniens Konig Juan Carlos stimmten in das Lob ein.

Ganz ungludklich dortten die ROmer Jedoch nicht sein, dass das Spektakel jetzt vortei ist. "Denn die menigsten haben won dem Ansturm der Mitionen profitiert. Ein Kelliner einer Puzeria in der Innenatagt beschwert skch: "Wir sind leer ausgegangen." fr habe gedacht, wenat die Ploer kommen, merde er einen viel grdeeren Umsatz machen. "Aber die haben ja alle nur Sandwichs gegesven." Revtburants konmten skch de rumeist fugeneikchen Pagstonhanger "olfenbar micht leisten - kein Wunder, denn selbst der monatliche Facharbeiterlohn eines folen schmiltrt in einem romischen Restaurant we Eis in der Sonne.

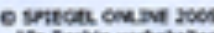

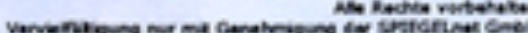

\section{Zum Thama:}

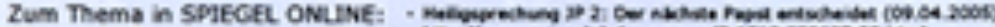

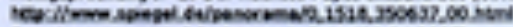

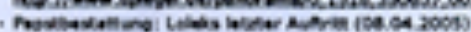

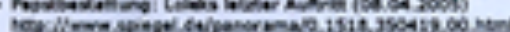

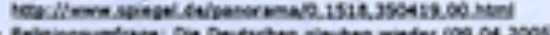

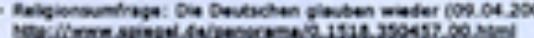

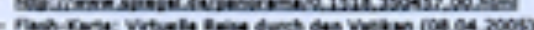

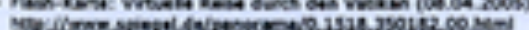

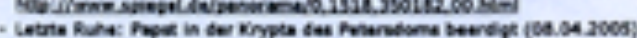

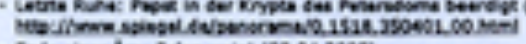

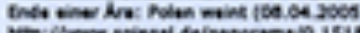

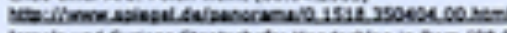

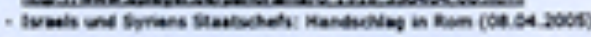

